\title{
How to Improve Classroom Atmosphere and Undergraduate Nutrition Students' Performance in Learning Nutrition Care Process?
}

\author{
Setyaningrum Rahmawaty, MHSc., PhD ${ }^{1}$ \\ 1Department of Nutrition Science, Faculty of Health Science, \\ Universitas Muhammadiyah Surakarta, Indonesia \\ email: setyaningrum_r@ums.ac.id
}

\begin{abstract}
Purpose: To investigate the implementation of Multiple Intelligences (MI) combined with map concept and portfolio assessment to improve classroom atmosphere and nutrition students' performance in learning nutrition care process (NCP). Methods: An individual action research project was implemented in the subject of basic dietetics involving 51 undergraduate nutrition students at the Department of Nutrition Science, Faculty of Health Science Universitas Muhammadiyah Surakarta, Indonesia. Results: Findings indicated that all students enjoyed the lectures; about $91 \%$ of them actively participated in the class; and more than half of the students were found to be more creative in completing the dietetics tasks. The assumption of most students that the subject of dietetics is scourge and difficult, turned into an exciting, relaxed but serious and easy to understand tasks, because students could learn using their own intelligence. The map concept and portfolio assessment trained students to be more thorough and disciplined in doing NCP. The average score of students' achievements at the end of semester indicated a very satisfactory category.
\end{abstract}

Keywords: Classroom atmosphere; concept map; Multiple Intelligences; performance; portfolio; nutrition students.

\section{Introduction}

In Indonesia, the subject of dietetics is a compulsory subject which must be completed by each undergraduate nutrition students before they undertake clinical practice in hospital. The topic of dietetics include nutrition care process (NCP) in hospital setting for adults and pediatric patients with various disorders, such as nutritional deficiencies, infectious diseases, gastrointestinal disorders, eating disorders, etc. There are a number of prerequisite subjects in the previous semester that must be completed by each student before 
undertaking this subject. The prerequisite subjects include anatomy, basic nutrition sciences, nutrition during life cycle, nutritional assessment, culinary, nutritional biochemistry, energy and nutrition metabolism, and pathophysiology. Due to the number and complexity of these prerequisite subjects, most of the students label dietetics as a scourge subject. In addition, a weekly NCP task and practice of processing and serving menu in laboratory based on the weekly cases were considered burdensome by most students learning dietetics. Moreover, they have different backgrounds and varying degree of interest in learning the NCP which encompasses a wide range of proficiency levels. An evaluation of students' performance including participation and creativity in class showed a big-gap phenomenon between students with high achievement rank and those with average or low score. The students' performance in class tend to be dominated by those who were in the high-performance level (Rahmawaty, Hidayati \& Kurnia, 2007).

Various active learning strategies have been employed to actively engage students in the dietetic class. Examples include group discussions and case studies or problem solving taken from cases in hospital, as well as portfolio assessment specifically designed for teaching dietetics. Together with the portfolio, a mentoring method by senior students had been implemented which showed a significant increase in students' ability in performing NCP as compared to conventional evaluation methods. However, even this method did not reduce the impression of most of the students that dietetics is a difficult subject. More than half of the students faced time-constraint in finishing the portfolio tasks, especially in designing a nutritional prescription for specific diseases (Rahmawaty et al., 2007). This phenomenon has persisted for years and it seems to affect classroom atmosphere as well as readiness of the students in the classroom. Teachers are constantly faced with the question of how to improve student participation and self-confidence in the class. Thus, it is generally perceived that improving students' performance in learning dietetics is difficult.

Classroom atmosphere reflects the quality of learning just as it affects students' performance. A good classroom atmosphere is characterized by a pleasant interaction between teacher and students during learning process. A positive classroom atmosphere is very important for students to learn and grow. Teachers as well as students feel comfortable in such atmosphere while students in particular are enthusiastic and confident to follow the lesson. Research indicates that a positive classroom atmosphere improves student achievement and confidence (LaTerra \& Dylinda, 2012).

There are various strategies that can be adopted to create a positive classroom atmosphere, such as always thinking and acting positively. Being positive does not mean being happy all of the time. Rather being positive means approaching every issue with a positive and constructive attitude. Teachers should understand that each student is a unique individual with their specific background and intelligence level that can be optimized to improve his/her performance. Research showed that learning strategies by optimizing the talent of each student improves student's participation in the class. As a result, 
students feel more confident and they try to improve their engagement in class. A classroom with more student engagement can be more productive. With this background, the current action research applied learning strategy by involving students' intelligences using Multiple Intelligences (MI) from Howard Gardner (Campbell, Bruce \& Dee, 2006) integrated with the concept of mapping and portfolio assessment.

MI offer a fun and smart learning process but it does not leave the scientific point of view in the learning process. The theory explained intelligence as the talent to solve problems or create products that are appreciated in one or more cultures or communities. The model is based on the notion that each individual has a unique intelligence or frame of mind that could be classified into linguistic, musical, logical-mathematical, visual spatial, interpersonal and intrapersonal intelligence. The involvement of individual frame of mind in the learning process is a fundamental factor in improving individual's performance in understanding topics as well as boosting their self-confidence. Numerous aspects of students' habit of learning and their learning behavior are associated with each other just as they are linked to the individual student's performance. The practices of MI concluded improvements in learners' skills, since they offering variety of activities allowing students to express their strengths and explore new paths of learning (NCSALL, 2006). The aim of this study was to explore the effect of implementing $\mathrm{MI}$ and map concepts learning method together with portfolio assessment on classroom practice and performance of students in NCP.

\section{Material and Methods}

\subsection{Study design}

This study was chategorized individual action research. John Elliott (1991) defines "action research is the process through which teachers collaborate in evaluating their practice jointly; raise awareness of their personal theory; articulate a shared conception of values; try out new strategies to render the values expressed in their practice more consistent with educational values they espouse; record their work in a form which is readily available to and understandable by other teachers; and thus develop a shared theory of teaching by research practice." While word individual refered to the teacher alone (the author, SR) performs the research of her subject which is basic dietetics in her class by implementing MI and map concepts learning method together with portfolio assessment.

\subsection{Respondent}

Fifty-one undergraduate nutrition students, which was a total number of students in a class who undertook the dietetics subject at the Department of Nutrition Science, Faculty of Health Science, Universitas Muhammadiyah Surakarta Indonesia participated in this study. Each student signed an inform concern to participate in this study. 


\subsection{Research steps}

The study was conducted in 3 stages, namely: 1) preparation, 2) presentation, and 3 ) analysis and validation. In the preparation stage, a survey was conducted to identify, evaluate, and formulate issues that are considered critical in using $\mathrm{MI}$ in terms of learning process and facilities required. The preparation includes designing a one-semester course outline, a lesson plan, handouts for each meeting, clarification materials in a power point view, a reflection for each meeting and the organization of the student's portfolio process and assessment techniques. All designed activities were based on the literature review and some research journals relevant to the MI theory. After all the materials in the planning stage were well-structured and complete, an experimental model of MI-based active learning was conducted during the first half of the semester. Evaluation results in the first half of the semester were used to improve lectures in the final half of the semester. The MI-based active learning used in this study is learning with teaching strategies that give students the opportunity to be actively involved based on their experience or their intelligence. Various elements of intelligence include linguistic intelligence, musical intelligence, logical-mathematical intelligence, visual-spatial intelligence, bodily-kinesthetic intelligence, interpersonal intelligence, intrapersonal intelligence, and naturalist intelligence (Campbell et al., 2006).

In the implementation stage, the learning model was carried out through several stages consisting of: (1) orientation, (2) idea generating, (3) idea structuring, (4) application, 5) clarification and (6) reflection. According to Needham's (1987) constructivism theory, this gradual teaching and learning strategy gives students the opportunity to make knowledge considerations that they already have in the process of fostering new knowledge. This is because each individual has a different "frame of mind" that will translate any information that is owned based on the intelligence he/she has. In the orientation phase, the lecturer drew the attention and interest of the students and motivated to continue to be interested in the teaching given by raising the problem to be considered. In the phase of idea generating, the lecturer asked questions and answers that encouraged students' thinking, so that the lecturer knew the alternative framework of the students. In the structuring phase of the idea, students were given the opportunity to understand new information/ideas according to their own intelligence, which can then be applied in new situations which were the new ideas themselves (the application phase of the idea). In this application stage, students in a group were asked to internalize and build their own conceptual map. The map concept in this study is defined as a map connecting concepts with lines and name the lines with one or more keywords with a proposition that express the meaning of relation (Gomes, Dias-Coelho, Cavalheiro \& Siqueira-Batista, 2011). The map must address pathophysiology and nutrition care process aspect of a patient with specific disease including nutritional assessment, nutrition diagnosis, nutrition intervention and nutrition monitoring and evaluation. At the end of this phase, the lecturer clarified the section using a power point presentation. The series of this stages were ended with a reflection aimed to assess the extent to which new information has been mastered by the students. All the student learning process was documented in a folio process 
called portfolio evaluation under supervision of a mentor. In this study, portfolio is defined as a collection of facts or evidence and documents in the form of tasks that are systematically integrated from a learner individually (Dawn, 2005) and specifically designed for the subject of basic dietetics (Rahmawaty et al., 2007). Table 1 shows the structure and organization of portfolio for the subject of basic dietetics. The mentor was a nutrition student who has took the dietetic course and passed the selection as a mentor. The aims of the mentoring activities were to support and motivate students in completing portfolio tasks and to bridge communication between students and teachers, especially students with less efficiency in communication. The mentoring was done once a week followed by the mentor reporting the mentoring process to the lecturer periodically.

Table 1: Structure and organization of portfolio for the subject of basic dietetics

1. Title page contains name, student number and class

2. List of contents

3. Main section consists of:

a. Introduction

b. Main tasks

a) Fill out learning phyloshopy and type of lerning form.

b) Fill out a weekly self assessment form after attending a class

c) The role of diet for healing of patients

d) Type and composition of commersial enteral formula and parenteral feeding

e) Map concept of nutrition care process (NCP)

f) Map concept of NCP for esophagitis, gastritis and peptic ulcer and fill out the NCP form based on the cases

g) Map concept of NCP for typhus abdominals, diarrhoea and malabsorption and fill out the NCP form based on the cases

h) Map concept of NCP for tuberculosis, bronchopneumonia and dengue fever and fill out the NCP form based on the cases

i) Map concept of NCP for colitis and diverticulosis and fill out the NCP form based on the cases

j) Map concept of NCP for hepatitis and cirrhosis hepatic and fill out the NCP form based on the cases

k) Map concept of NCP for NCP pada cholecystitis, cholelithiasis and pancreatitis and fill out the NCP form based on the cases

1) Map concept of NCP for malnutrition, anemia gizi, nutrition deficiency and fill out the NCP form based on the cases

m) Map concept of NCP for anorexia dan bulimia and fill out the NCP form based on the cases

4. Fill out a portfolio evaluation

\subsection{Data collection}

Data collected in this project including classroom atmosphere and students' performance in learning NCP. The classroom atmosphere data was collected based on observation of the student's participation in the classroom and creativity in presenting concept maps of $\mathrm{NCP}$, while student's performance data was obtained based on portfolio evaluation. In addition, each student also be asked to fill out a questionnaire to express his/her participation and creativity 
during following the class. The aspect of the portfolio assessment consists of 4 items, namely: (1) completeness (15\%); (2) tidiness (15\%); (3) individual tasks of $\mathrm{NCP}(35 \%)$; and (4) group assignment in the form of concept maps $(35 \%)$. The final score of the portfolio was combined with the semester score, and the score of the practical in laboratory.

\subsection{Data analysis}

A content analysis of student journals was used to identify keywords or phrases of student's response/perception on classroom atmosphere during following the class. While, an authentic assessment technique was used to analyse student portfolio based on a rubric specifically designed for the subject basic dietetics.

\section{Results}

\subsection{Instructional design of basic dietetic course using MI approach.}

The main objective of this research was how to create a conducive classroom atmosphere for teaching and learning process that could improve students' skill in NCP using a portfolio assessment model. An approach called MI which is popular as a smart and fun learning method has been applied to achieve this goal. The advantage of learning strategy using MI is to optimize the intelligence of each student in the learning process, without leaving the scientific side. A teacher is responsible for designing teaching process which can optimize the intelligence of each student enabling them to understand a concept/topic in a better way. The advantage of this technique is that students feel more comfortable and they understand the topics easily because what they are asked to do is in accordance with their habits.

The determination of the different types of intelligence used in each meeting was designed based on instructional objectives (IO), especially on defined verbs. Before translating the IO into an instructional design, the researcher constructed several key words 'verb' and alternative 'intelligence' which could be applied in class to assist student's activities in each meeting. Pairs of the verbs and the intelligences have been developed and presented in Table 2. Table 3 illustrates an example of a lesson plan designed using the MI learning model for dietetic course by involving a number of intelligences, as well as the stages in the classroom learning activities. 
Table 2: Pair of verb and alternative of intelligence in designing learning using multiple intelligence for the subject of basic dietetics

\begin{tabular}{|l|l|l|}
\hline \multicolumn{1}{|c|}{ Verb } & \multicolumn{1}{|c|}{ Intelligences } & \multicolumn{1}{c|}{ Activities } \\
\hline $\begin{array}{l}\text { Understand } \\
\text { definitions }\end{array}$ & Linguistic & Reading \\
\hline Understand a concept & $\begin{array}{l}\text { Linguistic, visual-spatial, } \\
\text { interpersonal }\end{array}$ & $\begin{array}{l}\text { Reading, arrange a map } \\
\text { concept }\end{array}$ \\
\hline Explain a concept & $\begin{array}{l}\text { Intrapersonal, visual- } \\
\text { spatial, musical }\end{array}$ & $\begin{array}{l}\text { Explain to other students, } \\
\text { group discussion, create } \\
\text { poem/song/lyric, design a } \\
\text { drama }\end{array}$ \\
\hline $\begin{array}{l}\text { Design a nutrition } \\
\text { care }\end{array}$ & $\begin{array}{l}\text { Interpersonal, } \\
\text { intrapersonal }\end{array}$ & $\begin{array}{l}\text { Accomplish nutrition care } \\
\text { process and explain to other } \\
\text { students, group discussion }\end{array}$ \\
\hline
\end{tabular}

Table 3: Example of lesson plan matric of the subject of basic dietetics using Multiple Intelligence Model

\begin{tabular}{|c|c|c|c|c|c|c|c|c|}
\hline \multirow{2}{*}{ Instructional outcomes } & \multirow{2}{*}{$\begin{array}{l}\text { Student's } \\
\text { activity }\end{array}$} & \multirow{2}{*}{$\begin{array}{c}\text { Material } \\
\text { Referen } \\
\text { ce }\end{array}$} & \multicolumn{6}{|c|}{ Learning activities (100 mnt) } \\
\hline & & & Orientation & Idea splitting & Idea structuring & Application & Clarification & Reflection \\
\hline \multirow[t]{2}{*}{$\begin{array}{l}\text { To understand definition of } \\
\text { dietetics, clinical nutrition, } \\
\text { diet therapy, nutrition care } \\
\text { and history of dietetics } \\
\text { - To explain the role of diet for } \\
\text { patient healing } \\
\text { - To explain the influence of } \\
\text { diseseas to the appetite, } \\
\text { chewing, swallowing, } \\
\text { digestion, absorption of food } \\
\text { and nutrients utilisation } \\
\text {-To explain factors influence } \\
\text { nutritional therapy }\end{array}$} & \multirow[t]{2}{*}{$\begin{array}{l}\text { VS } \\
\text { (design a } \\
\text { map } \\
\text { concept) } \\
\text { Ip, Ipa } \\
\text { (explain to } \\
\text { other } \\
\text { students, } \\
\text { group } \\
\text { discussion) }\end{array}$} & \multirow[t]{2}{*}{$\begin{array}{l}\text { Dietetics } \\
\text { book }\end{array}$} & $\begin{array}{l}\text { Lecturer } \\
\text { Show a picture/slide } \\
\text { about criticall ill patient } \\
\text { and explain it briefly } \\
(15 \mathrm{mnt})\end{array}$ & $\begin{array}{l}\text { Lecturer } \\
\text { - Explore students' } \\
\text { thingking framework by } \\
\text { asking "What will you do } \\
\text { as a dietitian to help } \\
\text { patients ?" in telation the } \\
\text { the orientation phase } \\
\text { (10 mnt) } \\
\text { - Divide students in several } \\
\text { group of intelligences and } \\
\text { ask them to choose a } \\
\text { leader and secretary in } \\
\text { each group ( } 5 \text { mnt) }\end{array}$ & $\begin{array}{l}\frac{\text { Students }}{\text { Read the dietetic }} \\
\text { book and discuss } \\
\text { the topic in a } \\
\text { group (15 menit) }\end{array}$ & $\begin{array}{l}\text { Group } \\
\text { Design a map } \\
\frac{\text { concept \& present it }}{(45 \mathrm{mnt})}\end{array}$ & $\begin{array}{l}\text { Lecturer } \\
\text { Clarify the } \\
\text { topic } \\
(10 \mathrm{mnt})\end{array}$ & $\begin{array}{l}\text { Students } \\
\text { Fill our a } \\
\text { self } \\
\text { assessment } \\
\text { form } \\
(5 \mathrm{mnt})\end{array}$ \\
\hline & & & VS & & B, Ip, Ipa & Ip, Ipa, VS & VS & Ipa \\
\hline \multirow[t]{2}{*}{$\begin{array}{l}\text { To explain definition of tifus } \\
\text { abdominals, diarrhoe, } \\
\text { malabsorption } \\
\text { To understand the etiology } \\
\text { To explain the principles of } \\
\text { nutrition care }\end{array}$} & \multirow[t]{2}{*}{$\begin{array}{l}\text { B (writing) } \\
\text { VS } \\
\text { VS } \\
\text { (design a } \\
\text { map } \\
\text { concept) } \\
\text { Ip, Ipa } \\
\text { (explain to } \\
\text { other } \\
\text { students, } \\
\text { group } \\
\text { discussion) }\end{array}$} & \multirow[t]{2}{*}{$\begin{array}{l}\text { Dietetics } \\
\text { book }\end{array}$} & $\begin{array}{l}\text { Lecturer } \\
\text { Show a normal GI tract } \\
\text { especially intestine and } \\
\text { briefly explain if there is } \\
\text { disorder in the intestine } \\
\text { such as an individu } \\
\text { consumed food/drink } \\
\text { containing microbia, it } \\
\text { can influence absorption } \\
\text { and utilisation of } \\
\text { nutrients in the human } \\
\text { body ( } 10 \mathrm{mnt})\end{array}$ & $\begin{array}{l}\text { Lecturer } \\
\text { - Explore students' thingking } \\
\text { framework by asking 'Do } \\
\text { you know about diseases in } \\
\text { the intestine influenced } \\
\text { nutritional status of } \\
\text { patients, including tifus } \\
\text { abdominals, diarrhoe and } \\
\text { malabsorption?" (10 mnt) } \\
\text { - Divide students in several } \\
\text { group of itellligences and } \\
\text { ask them to choose a leader } \\
\text { and secretary in each group } \\
(5 \mathrm{mnt})\end{array}$ & $\begin{array}{l}\text { Students } \\
\text { Read the dietetic } \\
\text { book and discuss } \\
\text { the topic in a } \\
\text { group ( } 15 \text { menit) } \\
\text { Answer questions } \\
\text { in the cases in the } \\
\text { book ( } 30 \text { menit) }\end{array}$ & $\begin{array}{l}\text { Group } \\
\text { Design a map } \\
\text { concept. } \\
\text { Present and explain } \\
\text { the concept using } \\
\text { their intelligences, } \\
\text { e.g. musical } \\
\text { intelligence } \\
\text { Alternatif node: } \\
\text { - Cokelat-Bendera } \\
\text { - Sherina feat } \\
\text { Marcello-Ayo } \\
\text { Indonesia Bisa } \\
\text { - Twenty first } \\
\text { night-Selamanya } \\
\text { Indonesia } \\
\text { (30 mnt) }\end{array}$ & $\begin{array}{l}\text { Lecturer } \\
\text { Clarify the } \\
\text { topic } \\
(10 \mathrm{mnt})\end{array}$ & $\begin{array}{l}\text { Students } \\
\text { Fill our a } \\
\text { self } \\
\text { assessment } \\
\text { form } \\
(5 \mathrm{mnt})\end{array}$ \\
\hline & & & VS & & L, Ip, Ipa & Ip, Ipa, VS, M & VS & Ipa \\
\hline
\end{tabular}


In each classroom meeting, the learning process was sequentially designed including orientation, idea-triggering, idea-setting, application, clarification and reflection. According to Needham's (1987) constructivism theory, the adoption of this gradual teaching and learning strategy would provide learners with the opportunity to make their knowledge considerations in the process of fostering new knowledge. This is because each individual has a different "frame of mind" that would translate any information that is owned based on their own intelligence.

Based on the results of the trial in the first half of the semester, it appeared that all designs and instructional instruments using the MI that have been designed could be applied properly. This was supported by a 'Manual of Dietetic Course' which contains study plan in a semester, weekly meeting design along with the type of evaluation and time allocation to do it, as well as all instruments used for preparing the portfolio tasks and assessment rubrics. The handbook was distributed among students and explanation on how to use it was provided at the beginning of the meeting. Thus, the students already had a picture of what they will do for a semester. The organization of the portfolio along with the instruments used were developed from previous research conducted by researchers (Rahmawaty et al., 2007) by adjusting the development of dietetics topics and learning design using the MI. A map concept of each topic was added in the portfolio assessment in order to make easier students' in learning NCP. It enabled students in explaining and examining the principles of nutritional care of patients with certain diseases. Understanding the correct map concept determined the success of students in completing portfolio assessment. Therefore, students were asked to explain the concept map using their intelligence. As an example provided in Table 1, students were asked to compose concept maps into a song lyric. Without understanding the concept of disease and diet management, the arrangement lyrics of the song also be mistaken.

\title{
3.2. Implementation of the learning model using MI
}

The following poetry, song lyric, story, crossword and poster were examples of the students' works during the dietetic course by applying MI.

\section{Poetry (Musical Intelligence)}

\author{
NCP on Chronic Diseases, by AJP \\ “Just like a former ... \\ You have to get away from me \\ Like my former boyfriend, REGA \\ You can only hurt me \\ Still very clear \\ How you made me fall \\ You let me nausea, vomiting and fever \\ I have no appetite and my weigh was decreased \\ Not only that, you hurt me \\ You bear my abdominal pain
}


I suffered from chronic diarrhea

I've experienced intestinal bleeding

I knew you hurt me for a reason

You had an abnormal autoimmune

You had an inflammation

Then the permeability of the intestine and ROS increased, then damaged my network

I understood, that was why you hurt me

But indeed we were not mate

I had to leave you

Whatever I did to stay away from you

I increased energy as needed

When I was suffered from steatorrhea, I reduced my fat consumption

When there was a fistula in my body, I ate low fat and waste diet

When I had lactose intolerant, I will consume low lactose milk

Or not even at all

When I had gluten intolerant, I had to be wary of the source of gluten

I had to leave you,

I consumed vitamin and mineral supplementation

Then ate small portions and often

With that you would not be able to pair with me"

\section{Song (Musical intelligence)}

NCP on Malabsorbsi - cover song Flag by Cokelat

"Malabsorption, here there are three types, namely fat, protein, lactose intolerant Malabsorption of fat caused by liver disease, pancreas, small intestine and lymphatic abnormalities Diagnosis is seen from the results of the stool lab It is macroscopic and also microscopic With a diet that should be low in fat Source of fat from triglyceride chain medium The number two is protein malabsorption The etiology is allergic to Protein in cow's milk ...

$(2 \mathrm{x})$

There is a lack of trypsin activity

Due to lack of nutrition and also chronic diarrhea

Keep my intestines healthy

I will always take care of you

Dietary management use protein sources

From soy or hydrolyzed protein

Symptoms LI is a stomach so bloated

Fluid stool diarrhea and frequent waste of angina

Abdominal colic is symptomatic of LI

The $\mathrm{pH}$ of the stool is less than six

It's diet management

$(2 \mathrm{x})$

Low lactose nutrient milk

For breast feeding support, secondary case one month 
Keep my intestines healthy

I will always take care of you"

\section{Story (Linguistic intelligence)}

\section{NCP for gut and small intestine problem: 'ILEUM AND COLON DEMONSTRATION"}

"Raindrop represents the heart's liver. His mind flew away in the dark cloud. Sitting pensively behind the window while staring at the tetsan water falling down the earth. One of the countries famous for its prosperity and prosperity began to show its shakiness. A country known as the Human Body began to reap a lot of criticism. Ileum and the colon is one of the colors of the State of the Human Body that feels justice begins to shrink. They plan to hold a demo demanding the death penalty for Inflammatory Bowl Disease (IBD) and his colleague Crohn Disease and ulcerative colitis and diverticulosis. The demands are based on the facts that confirm that they are the cause of disruption of lower gastrointestinal tract in human body, especially on ileum and colon. Because ileum and colon have become victims of their ferocity.

"Give them punishment", said one of the demonstrators. "Do not let disease live and grow in their country", says the ileum. "Yo ... Yo ... Attack ... Attack ... give justice for us pack", kara intestine. Such are those who convey their aspirations through demonstrations, because their complaints are ignored by the People's Deputy.

Intestine itself has problems with Inflammatory Bowel Disease (IBD). Initially the intestines are fine. Then the gut undergoes a mutation of the gene that causes the immune response to become abnormal, then cause an inflammation and increased bowel permeability, followed by tissue damage. These incidents caused IBD to attack the intestines and cause symptoms that would cause the Human Body State to lose and decrease the welfare of the people of the Human Body. The symptoms of ibd's loss are diarrhea, fever, $\mathrm{BB}$ loss, anemia, intolerance, malnutrition, failure to grow and dermatologists. Not only that IBD also invites two friends to destroy the country, Crohn and ulcerative colitis. Crohn was assigned to attack the ileum with his cunning, Crohn makes ileum into granules - fat granules that make the small intestine and intestinal wall thicken, and often strictures, inflammation and malabsorption. It is Crohn's way of entering and attacking the ileum to bring down the state of the Human Body. So the resulting losses are bloody stools, diarrhea, stomach pain, intestinal thickening, fever, stomatitis, and anorexia that cause the country to decline.

On different days and in different places, a beautiful afternoon lays out the twilight light that deliberately illuminates the heart of the rejoicing Colon. But the light was suddenly dimmed dark clouds. Along with the emergence of dark clouds, infections appear ready to cause inflammation in the colon. Investigate a cutaneous investigation is a hitman hired by ulcerative colitis. After inflammation of the intestine, panic disorders and paralysis. That's when the ulcerative colitis enters and combats the intestine. It is of course bad for the country, because it causes symptoms that will certainly affect the stability of the country, namely diarrhea, bloody stool, peut pain, anemia, 
fever, stomatitis, and nutritional crisis. As a result of ulcerative colitis, the state declines marked by bloody diarrhea, slight stricture, inflammation, deep ulcers, but no thickening of the intestinal wall. Comes with it, the infection also attacks the colon, but causes diverticulosis. This happens due to countries that consume lots of fast food containing low fiber. It is this country's fault that causes the people, the gut suffering from diverticulosis. Diverticulosis causes symptoms and signs that cause decline of the state and the welfare of disturbed people, namely colic, inflammation, and bleeding.

The demonstrators demanded that the president issue a Presidential Regulation quickly and appropriately. After the ileum and colon that became the representative of the protesting demonstrators, the president also issued Presidential Regulation no. 20 years 3016 to execute IBD. Crohn, ulcerative colitis and diverticulosis hope will no longer appear to interfere with prosperity, prosperity, stability, and state defense. The Perpres is to deal with Crohn and Ulcerative colitis in order not to come again to provide energy as needed to prevent $\mathrm{BB}$ reduction (1.3-1.5x from BM), high protein (1-1.5 g / kg BW daily), free or low lactose feeding, maintaining fluid and electrolyte balance, given low residual foods that do not aggravate gastrointestinal work and give oral food in small but frequent portions. While the Perpres for diverticulosis is given low water soluble fiber and coarse fiber in the acute period, given enough fiber food to dilute the bowel, given fiber bit by bit until it can be tolerated fiber and given enough fluids to maintain the consistency of bowel movements. The purpose of the issued Perpres is to reduce mechanical irritation and inflammation of the intestines, maintain fluid and electrolyte balance, rest the intestines, improve intolerance, and improve nutritional status due to nutritional crisis in the country. With the issuing of the Presidential Regulation and the state government of Human Body hope no more provocateur of state diseases that want to destroy the country. The State of the Human Body can also return prosperous and prosper safely". 


\section{Protect Galbladder Protect Your Health}
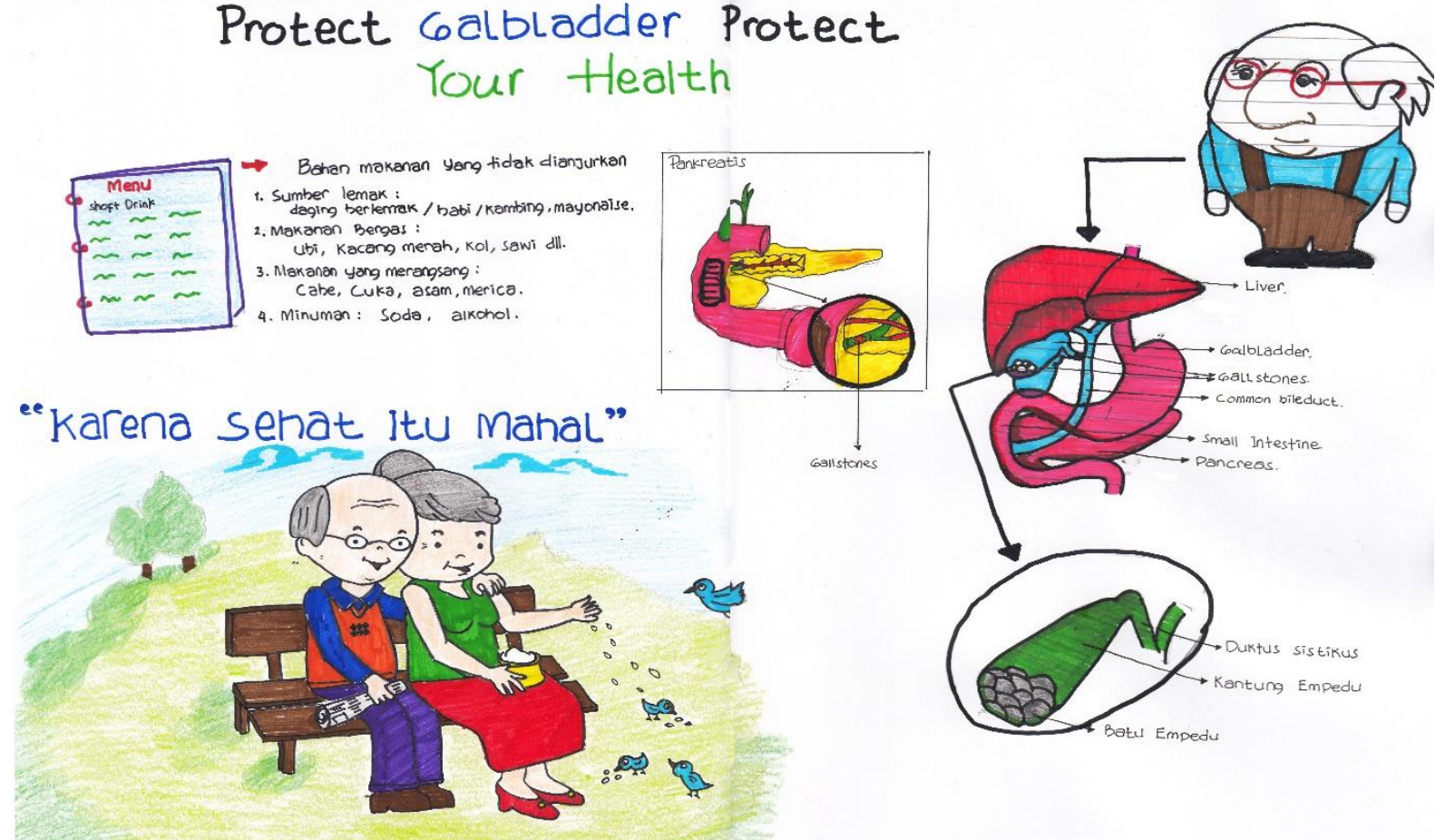

Figure 1: Poster example of a student group work in mapping a concept of NCP for gallbladder disease.

\subsection{Participation, creativity and performance of students}

The effectiveness of implementation of the MI learning model in this study was assessed based on the student's participation in the classroom, creativity in presenting concept maps and performance in doing NCP using portfolio evaluation. The aspect of the portfolio assessment consists of completeness, tidiness, individual tasks of NCP, and group assignment in the form of concept maps. The oral test which was a part of the portfolio assessment in the previous study (Rahmawaty et al., 2007) was excluded in this study. The consideration was to avoid duplicate judgments, where the students' ability in communication or argumentation implicitly becomes a part of group activity in designing concept map as well as practicing in laboratory or cooking the menu of NCP.

\subsubsection{Participation of students in classroom}

Based on the observation of the students' participation in the classroom during the learning process, it was observed that all students were actively involved in group discussion activities, preparing and presenting their concept maps. During classroom teaching, all students felt happy and were not bored during the lecture in classroom. Of the 16 classroom meetings in the semester (including midterms and final exams), 90.9\% (50 students) attended all the meetings, while the remaining 3 students attended 14 times and 2 students attended 13 times. Our findings suggest that the application of MI model could increase students' activity in the class and gradually change the assumption of most students that dietetics is scourge and difficult subject. Instead, it turned into an exciting and 
relaxed but serious and easy to understand tasks because students could learn using their own intelligence, as can be seen in the following statements by the students:

"What I feel during my studies with MI, I feel learning with my own 'style'. That way it make me become easily and actively developed with the learning of MI."

"The applied MI learning adds to the level of understanding in the given material, more confidence and active in the learning process and discussion, and the level of creativity is increasingly honed."

"I feel required to be more active as well as creative in MI learning system, and must be more systematic and structured in the process of material understanding"

"With the MI method I feel more active, other than that the atmosphere in the class does not make students bored or sleepy"

"The author was afraid at the beginning of the lecture. Many benefits are felt during the learning process is not only a developing ability but also a new experience when understanding the material with multiple intelligence methods so that learning is not boring anymore. The atmosphere in the class become enjoy and fun no longer tense let alone make students sleepy. "

"From the beginning of entering the lecture the author felt the lecture is very creepy, coupled with stories from the level and the beginning of the graduation of assignments in this course. After undergoing the lecture, it turns out the atmosphere is fun by way of learning multiple intelligence because according to their respective skills. The author is happy because it can be easier to remember the material presented by each group at the time of recovery."

"At first I was afraid, because of the responses from the older siblings who have followed the Dietetic, because dietetic is a difficult course. However, as time passes, it becomes increasingly accustomed to the case and becomes increasingly attractive to follow. Multiple intelligence is a fun learning method, because it is required to learn in accordance with the talent so as not to cause saturation. "

"Multiple Intelligence which actually makes the learning that we get fun because adjusted with the ability / intelligence we have. The author gets unimaginable learning from every assignment."

\subsubsection{Creativity of learners in performing portfolio task}

Increased creativity is a positive element that resulted in applying learning using MI. By applying MI, students are expected to be more able to optimize their own creativity, either individually or in group form, for example when establishing a strategy or technique to be used when presenting concept maps to other groups. Of course this is tailored to the intelligence of each students so they will feel comfortable and will enjoy doing it. The purpose is to change the impression from "difficult" to "fun and easy." Based on the final evaluation of the portfolio, most of the learners were found to be more creative and innovative in following 
the lectures with MI and they enjoyed the lectures. This is evident from some examples of learners' expressions as follows:

"Learning by using multiple intelligence students are required to be creative in accordance with their respective talents. Of course this makes the authors feel enjoy following the lecture because the learning method is different from usual. Apparently this course is not scary".

"Beginning to take the subject of dietetics writers feel so scared, but began the passage of time and every week lecturers alternated the atmosphere to be relaxed towards this course, let alone the delivery of materials with learning media according to multiple intelligence methods. This makes it easier for authors to accept the material. Multiple intelligence makes students think creative and innovative. Lecture atmosphere enjoy and relax".

"Learning by using MI students are required to be creative in accordance with their respective talents, of course this makes the writer feel enjoy to follow the lecture because the method of learning is different than usual. The dietetics subject is not scary anymore".

"The lecture of dietetics is very memorable in the memory, because the author becomes more familiar and more mastered how to arrange a good nutritional care. Creating concept maps is very draining. Learning with multiple intelligence method based on the intelligence that the author has is to make short stories. At the beginning of the lecture the author thinks "nothing". It is very draining the imagination, because every week must be different themes. Alhamdulillah, the feeling of bad taste has gradually faded. The author finds pride because the tasks assigned refer to the reality of life in the hospital".

"The application of the MI method that suits me, namely musical intelligence, makes the course that I initially regarded as a scourge has turned into an exciting class in the class, as the presentation varies greatly in the delivery of the material, using poetry, poster, drama, drawing, concept maps and more. I feel the benefits in learning Dietetic Courses, learning nutrition though complicated but very fun. Over time, the NCP has started to get used to and can work on the case in a timely manner".

"Multiple intelligence is an interesting way of learning because students can be creative in accordance with their talents or hobbies. Creating a concept map is very helpful because it makes it easy to understand the characteristics of some diseases'.

\subsubsection{Performance of learners in the process of nutritional care}

Performance of student portfolio achievement was measured through quantitative score based on portfolio assessment, practice in laboratory, and students' positive comments on portfolio assignment. Table 4 and 5 present results of the portfolio assessment as well as final score of this project. 
Table 4. Results of portfolio evaluation

\begin{tabular}{lcccccc}
\hline \multicolumn{1}{c}{ Aspect of assessment } & $\mathrm{n}$ & Mean & Median & $\begin{array}{c}\text { Deviation } \\
\text { Standard }\end{array}$ & Minimal & Maximal \\
\hline Completeness (15\%) & 51 & 2.90 & 3.00 & 0.22 & 2.00 & 3.20 \\
Tidiness (15\%) & 51 & 3.01 & 3.00 & 0.18 & 2.60 & 3.40 \\
Individual tasks (35\%) & 51 & 3.09 & 3.20 & 0.22 & 2.00 & 3.60 \\
Group assignment (35\%) & 51 & 3.16 & 3.20 & 0.15 & 2.60 & 3.40 \\
Final score of portfolios & 51 & 3.05 & 3.05 & 0.15 & 2.60 & 3.40 \\
\hline
\end{tabular}

Table 5. Final Semester Scores

\begin{tabular}{lcccccc}
\hline \multicolumn{1}{c}{ Item of valuation } & $\mathrm{n}$ & Mean & Median & $\begin{array}{c}\text { Deviation } \\
\text { Standard }\end{array}$ & Minimal & Maximal \\
\hline Participation in class (5\%) & 51 & 3.90 & 4.00 & 1.23 & 3.40 & 4.00 \\
Portfolio (35\%) & 51 & 3.05 & 3.05 & 0.15 & 2.60 & 3.40 \\
Theoretical scores (30\%) & & & & & & \\
$\quad$ - Mid term semester & 51 & 2.50 & 2.50 & 0.28 & 1.72 & 3.10 \\
$\quad$ - Final semester & 51 & 2.30 & 2.24 & 0.31 & 1.70 & 3.05 \\
Practice in laboratory (30\%) & 51 & 3.00 & 2.98 & 1.23 & 2.98 & 3.05 \\
Final score & 51 & 2.90 & 2.92 & 0.10 & 2.70 & 3.13 \\
\hline Final score & 51 & 2.90 & 2.92 & 0.10 & 2.70 & 3.13 \\
\hline
\end{tabular}


Results of the final evaluation showed that the average performance of students in performing nutritional care was quite satisfactory (2.90) with a minimum value of 2.70 and a maximum of 3.13. Compared to the previous research using conventional learning method and portfolio evaluation, it could be seen that the average final score was not much different of 3.16 (Rahmawaty et al., 2007). Based on the students' responses to the portfolio tasks, none of them explained negative comments about the portfolio and they worked quite hard to complete it. Most of students stated that the portfolio assignments made them more disciplined, effective and efficient in organizing their time, acting more thoroughly and carefully, and becoming more creative in designing nutrition care, as the following phrases suggest:

"Portfolio duties make me more disciplined, able to organize and share time well."

"Portfolio work is very helpful to us in the process of learning dietetics, because it is felt more simple but informative because it has the core points and the importance of the material in each lecture."

"Portfolio work allows us to learn how to manage good time and act appropriately and thoroughly. The author is also required to always be creative in preparing the menu."

"Portfolio tasks make me more precise in filling out the NCP form."

All students expressed positive comments on the task of map concept that was done in groups. The task of maps concept has many benefits for students, including easy to understand material, easy to remember, and understanding the process of nutritional care of patients, as the following expressions indicate:

"Making tasks in the form of concept maps is very helpful in understanding the material writers. Drawing a concept map is done with a group of friends, so it can help less-understood students to ask group friends."

"Make the task by creating a concept map, making the students better understand and understand what is delivered. Concept maps are helpful in understanding the nature of each disease."

"The case given will be easy to do when the author understands the pathophysiology and metabolic processes of the body. The concept of the folder is very helpful for the writer because it makes it easier to remember (the concept of the folder made interesting and structured)."

"The task of concept maps provided to facilitate the author to know the flow of a disease, how the disease, what causes, symptoms occur, and how the diet should be given. However, by studying the weight of nutritionist assignments in hospitals through Mk Dietetics, the authors have come to understand how a patient's feelings put great expectations on nutritionists to help the healing process." 
"The task of drafting a concept map every week will be collected in portfolio later, making it easier to understand about the disease and nutritional problems experienced by patients."

Compared with conventional learning, MI method applied in MK Dietetic and Infectious Disease has many positive aspects especially in fostering confidence, creativity and activeness of learners in teaching and learning process, both in class and in laboratory. MI is synonymous with the learning model that "smart and fun" proved to foster a class atmosphere conducive for learning. Besides, learning becomes more interesting and fun because of the presentation of the various 'unique' intelligences that the learners have. Here are the various expressions of learners on the application of MI:

"By making songs and poems, we find it easier to understand the theory of dietetics. Lessons learned by lecturers are also very interesting and rarely performed by other lecturers."

"At the first time I got the task of Nutrition Care Process (NCP) the author felt surprised, several times have to repeat to justify the diagnosis. At that time the author felt annoyed, but eventually the author was happy with doing NCP, we more easily remember the material that has been learned."

"Over time, it turns out NCP is very interesting and cool. Creating concept maps, singing, drawing, making fun etc. makes learning dietetics easier, engrossed even eliminating the creepy specter of the famous, tense, stiff and even horror dietetics for nutrition students."

"The MI method simply helps relax the mind so that lecture material can be received more easily than conventional teaching."

"Learning by using multiple intelligence method makes it easier for students to understand the material because it is suitable with the ability. The task of creating concept maps and tasks with multiple intelligence is not too difficult because the task is done according to their intelligence."

"The MI method simply helps relax the mind so that lecture material can be received more easily than conventional teaching."

"Learning by using multiple intelligence method makes it easier for students to understand the material because it is suitable with the ability. The task of creating concept maps and tasks with multiple intelligence is not too difficult because the task is done according to interests and abilities."

"At the beginning of the course the author feels that dietetics is a scary course, but over time the author feels that dietetics is an exciting subject. Creating concept maps greatly facilitate the author in learning. More fun learning sharing with the method of multiple intelligence, because according to the ability of yourself. The task of the NCP is very interesting."

"There is a very interesting side to us because we are given a very unique task from the previous for the way of delivering the material with multiple intelligence. With this method so it can be easier to master about the materials of dietetics." 
"Originally the author thought it would only be taught about the kinds of diseases and their complications. Multiple intelligences methods used when PBM activities are fun. The writer is asked to explain the material of Dietetics with the talent that is owned, making it easier to understand the material and the PBM process more fun and not tense."

\section{Discussion}

The implementation of MI method in this study showed many positive effects as compared to the conventional learning method, especially in creating a pleasant learning environment and boosting the confidence and creativity of students in learning process. In addition, implementation of the MI proved to change the image of students regarding the subject of dietetics from scourge and difficult to be fun but still serious with the various unique presentation of students' intelligences. Portfolio assessments train students to be more disciplined, effective and efficient in managing their time. It also makes them more thorough and careful in analyzing cases and enhances their creativity and training skills in doing NCP. Similarly, the concept map task facilitated students in understanding materials of the subject of dietetics and doing NCP. Gagne (1985) and cit Fajar (2005) emphasized the importance of internal conditions including emotional conditions and external conditions in a lesson, in order for the students to achieve the expected learning outcomes.

Portfolio evaluation applied in this study improved students' performance in doing NCP. The principle of portfolio is in line with Tooemy et al. (2004) which states that an assessment should include several aspects, including: (1) accommodating the self-development perspective of learners, so an assessment should be sustainable, not only at a certain time level of intelligence and psychological condition of different learners, (2) assessment should focus on the learning process, (3) the assessment should be able to track the progress of the process by displaying the results obtained in what way the learners get the results, and (4) the assessment must be reputable, meaning that its validity must be accountable. The portfolio assessment has many advantages in learning process, including encouraging intensive collaboration (communication and relationship) between learners and teachers, educating learners to have the ability to reflect on their learning experiences, so that they are motivated to learn better. Moreover, the use of portfolio is in line with teaching for adults (andragogy), so that the learning experience retained in the memory of learners would be more durable due to the fact that the student has done a series of learning process from knowing, understanding the concept, doing activities and learning to cooperate with colleagues. All of this would ultimately provide the provision for learners in the togetherness of life in society as the goal of lifelong learning which is essentially preparing learners for a positive future (Meyer, 2002). However, the MI methods and portfolio evaluation also present some challenges to the teachers as they need to be more careful and prepared for designing learning methods and their completeness. They also need to be alert towards evaluating the results of learning activities according to the learning objectives and conditions of the students. The portfolio also help teachers better understand the characteristics of each student. Additionally, the evaluation 
process is time consuming for the teachers, since the evaluation is done simultaneously until each learner can achieve the established competencies. Besides, the creativity of teachers is also required in designing MI and portfolio along with the provision of components that support it.

\section{Conclusion}

In accordance with its objective, the result of this study is an MI-based learning model with map concept and portfolio assessment for the subject of dietetics for undergraduate nutrition students. The application of MI model and portfolio evaluation gave many positive effects in fostering an enjoyable and creative but serious classroom atmosphere. The original assumption that the subject of dietetics is scourge and difficult gradually turned into a pleasant and easy to understand subject because students can learn using their own intelligence. Preparation of concept maps and group presentations using each student's intelligence makes learning easier for them and makes students more creative, innovative, and self-confident. The portfolio trained students proved to be more disciplined and thorough in doing NCP. The average score of students' achievement at the end of semester indicated a very satisfactory category.

\section{Suggestions}

The learning model of MI could be used as one of the lecture methods especially for the subjects with portfolio tasks. This model was developed with the assumption that a fun but serious lecture atmosphere, by optimizing the intelligence of each learner, will help optimize them to perform complex portfolio tasks. This can optimize the performance of learners in performing nutritional care of patients. However, because of the simultaneous learning and assessment process and the practice in the laboratory, it is expected that the teacher will have a lecture design and evaluation method/process and will also provide complete material such as lecture book, textbook, forms to do the tasks, evaluation rubbers etc. If possible, the lecture load should also be adjusted. Similarly, supporting media for presentation of concept maps, such as audio visual, media, etc. should also be made available.

\section{Acknowledgments}

This work was supported by the Quality Insurance Agencies, Universitas Muhammadiyah Surakarta Indonesia under Teaching Grant "Learning Quality Improvement of A Subject".

\section{References}

Armstrong, T. (1994). Multiple Intelligences in the Classroom. Alexandria, VA: ASCD.

Campbell, L., Campbell, D., Dickinson, D. (1999). Teaching and learning through the multiple intelligences (2nd ed). Boston: Allyn and Bacon.

Fogarty, R., \& Stoehr, J. (1995). Integrating curricula with multiple intelligences: teams, themes and threads. Corwin Publishers.

Amstrong, T. (2004). Kamu itu lebih cerdas daripada yang kamu duga (You're smarter than you think). Batam Centre: Interaksa. 
Bransford, J. D., Brown, A. L., Cocking, R. R. (2000). How People Learn: Brain, Mind, Experience, and School. Washington DC: National Academy Press

Campbell, L, Bruce, C \& Dee, D (2006) Metode Praktis Pembelajaran berbasis Multiple Intelligences (Learning practical method based on multiple intelligences). Penyunting: Amir, K. dan Suryadi, N. Depok: Intuisi Press.

Coustan, T., \& Leslie, R. (1999). Putting Theory into Practice. Applying MI in the Classroom meant enhancing, rather than replacing, techniques we value. Focus on Basics, 3 (A), 21-24. http:// www.ncsall.net/index.html@id=369.html.

Depdiknas. (2004). Kerangka Dasar dan Struktur Program Departemen Pendidikan Nasional (Basic concept and structure of national education department). Jakarta.

Elliott, J. (1991). Action research for educational change, Open University Press, Milton Keynes.

Foster, P., N. (2005). Book Review: Weimer, M. (2002). Learner-centered teaching: Five key changes to practice. San Francisco: Jossey-Bass/Wiley. \$33 (hardcover), 258 pp. (ISBN 0-7879-5646-5). Excerpt available: www.josseybass.com. Journal of $\begin{array}{lllll}\text { Technology Education, } & 16 & \text { 72-76. }\end{array}$ https://scholar.lib.vt.edu/ejournals/JTE/v16n2/pdf/bookreview.pdf

Gardner, H. (1989). To open mind: Chinese Clues to Dilemma of Contemporary Education. New York: Basic Books.

Goleman, D. (1997). Emotional Intelligence. New York: Bantam Books

Gomes A. P., Dias-Coelho U. C., Cavalheiro P. O., Siqueira-Batista R. (2011). The role of concept maps in the medical education. Revista Brasileira De Educação Médica, 35 (2), 275-282. http://www.scielo.br/pdf/rbem/v35n2/en_18.pdf.

Kallenbach, S., \& Julie, V. (2002). Open to Interpretation: Multiple Intelligences Theory in Adult Literacy Education. Finding from the Adult Multiple Intelligences Study. NCSALL Reports. Harvard University Graduate School of Education. https://eric.ed.gov/?id=ED467242

LaTerra, W. \& Dylinda, W. (2012). Positive classroom environments = positive academic results. https://files.eric.ed.gov/fulltext/ED536465.pdf

Mudjijana, R. (2004). Hubungan antara Iklim Sekolah dan Kecerdasan Emosional Siswa dengan Prestasi Belajar Siswa (Correlation between school atmosphere and emotional intelligence of students and their learning achievements). Jurnal Pendidikan Penabur, 2, 82-100.

Moleong, L., J. (2002). Metodologi Penelitian Kualitatif (Qualitative Research Methodology). Bandung: PT Remaja Rosdakarya.

NCALL (2006). Seminar Guide: Adult multiple intelligences in practice. www.ncsall.net.

Needham, R. (1987). Teaching Strategies for Developing Understanding in Science. Leeds, Children's Learning in Science Project. University of Leeds.

Quinones, W., \& Besty, C. (1999) “I Can't Learn This!" An MI Route Around Resistance. Focus on Basics, 3 (A),10-13. http:// www.ncsall.net/index.php@id=372.html

Rahmawaty, S., Hidayati, L., Kurnia, P. (2007). Model Evaluasi Portofolio untuk Peningkatan Kompetensi Dietisien dan Lifelong Learning (Model of portfolio evaluation to improve dietetics competences and lifelong learning). Proceeding of the Research and Studies $V$, Dirjen PT Depdiknas.

Sugiharti, P. (2005). Penerapan Teori Multiple Intelligences dalam Pembelajaran Fisika (Application of Multiple Intelligence theory in subject of physic). Jurnal Pendidikan Penabur, 5, 29-42. 
Syamsuddin, A., R. \& Vismaia, S., D. (2006). Metode Penelitian Pendidikan Bahasa (Research methodology in language education). Postgraduate Universitas Pendidikan Indonesia and PT Remaja Rosdakarya. Bandung

Yulaewati, E. (2004). Kurikulum dan Pembelajaran (Curriculum and Learning). Bandung: Pakar Raya Pustaka. 